\title{
Enhanced Current Production by Electroactive Biofilm of Sulfate-Reducing Bacteria in the Microbial Fuel Cell
}

\author{
Numfon Eaktasang ${ }^{1,2}$, Christina S. Kang ${ }^{2}$, Song Jung Ryu' ${ }^{2}$, Yanasinee Suma ${ }^{1,2}$, Han S. Kim ${ }^{2 \dagger}$ \\ ${ }^{1}$ Department of Advanced Technology Fusion, Konkuk University, Seoul 143-701, Korea \\ ${ }^{2}$ Department of Environmental Engineering, Konkuk University, Seoul 143-701, Korea
}

Environ. Eng. Res. 2013;18(4):277-281.

http://dx.doi.org/10.4491/eer.2013.18.4.277

We found that an incorrect value of lactate concentration was provided in the Microbial Fuel Cell Operation section of the Materials and Methods. The MFC was supplied with $30-\mathrm{mM}$ and not 10-mM lactate medium. We apologize for any inconvenience that it may have caused.

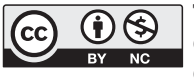

This is an Open Access article distributed under the terms of the Creative Commons Attribution Non-Commercial License (http://creativecommons.org/licenses/by-nc/3.0/) which permits unrestricted non-commercial use, distribution, and reproduction in any medium, provided the original work is properly cited.
${ }^{\dagger}$ Corresponding Author E-mail: hankim@konkuk.ac.kr Tel: +82-2-450-4092 Fax: +82-2-450-3542 